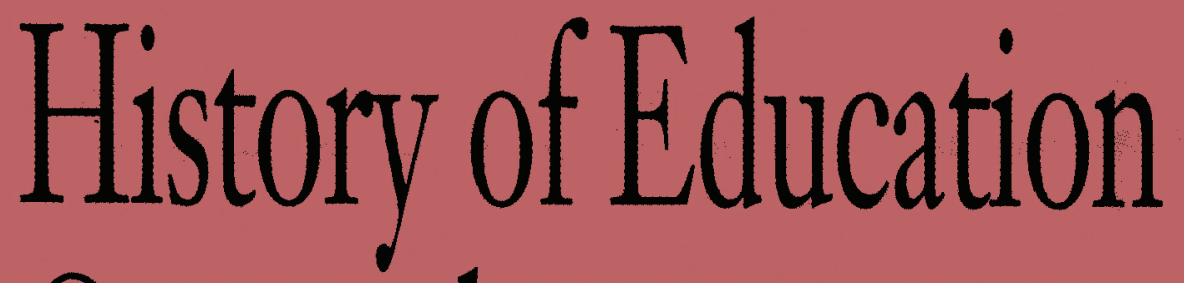

Quarterly

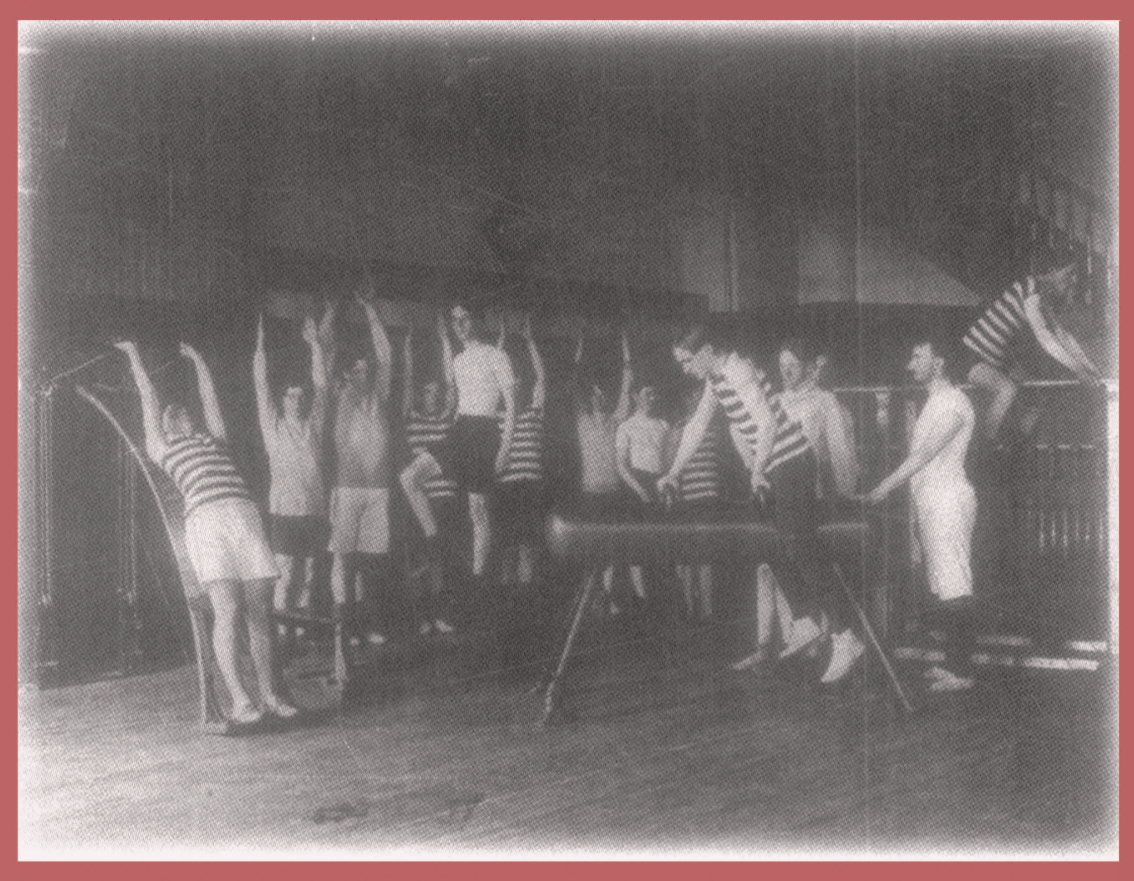

August 2008

Volume 48, Number 3 
THE CLAUDE A. EGGERTSEN DISSERTATION PRIZE: The History of Education Society is accepting submissions for the Claude A. Eggertsen Prize for the dissertation judged to be the most outstanding in the field of History of Education. The prize carries an award of $\$ 1,000$ for the winner. 2007 Committee members: Victoria-Maria MacDonald (Chair), Joy Williamson, Sevan Terzian.

2007 winner: Laura Kathryn Munoz, "Desert Dreams: Mexican American Education in Arizona, 1870-1930.” Arizona State University.

2007 honorable mentions:

Emily Straus, "The Making of the American School Crisis: Compton, California and the Death of the Suburban Dream," Brandeis University.

Andrea Lawrence, "Unraveling the White Man's Burden: A Critical Microhistory of Federal Indian Education Policy Implementation at Santa Clara Pueblo, 1902-1907," Indiana University.

Eggertsen Dissertation Award Committee for 2008:

Chair, Joy Williamson, (2005-2008) University of Washington

Sevan Terzian, (2006-2009) University of Florida

Maggie Nash, (2007-2010) University of California, Riverside

THE HISTORY OF EDUCATION BEST ARTICLE AWARD: The History of Education Society awards a prize of $\mathbf{\$ 5 0 0}$ biennially (in alternating years with the Henry Barnard Prize) for the best article in the history of education, broadly defined to cover a wide range of educational and cultural institutions inside and outside of the United States. This includes work on schools and universities, teachers, students, and families. The next award will be presented at the fall 2008 meeting of the History of Education Society. Articles published in journals during 2006 and 2007 (no book chapters) will be eligible. Self-nominations are also welcome. The postmark date for entries will be April 1, 2008. Check back for further submission information

THE HENRY BARNARD PRIZE: The History of Education Society awards the Henry Barnard Prize of $\$ 500$ biennially (in alternating years with the Best Article Prize) for the best graduate student essay in the history of education. Nominations by faculty, graduate advisers, department chairs, and deans, as well as self-nominations by students, are welcome. HES also extends a $\$ 250$ travel supplement to the Barnard Prize winner for his/her attendance at the annual meeting, and covers the costs of registration and the banquet. 2007 Committee Members: Peter Wallenstein (Chair), Michael Fultz, Chris Ogren, Adah Ward Randolph, Christine Woyshner.

2007 Winner: Paul J. Ramsey, Indiana University. "In the Region of Babel: Public Bilingual Schooling in the Midwest, 1840s-1880s."

2007 Honorable Mention: Katherine Sedgwick, University of Pennsylvania. "From Hazing to Socialization: A History of Social Conformity and Freshman Orientation."

Barnard Prize Committee for 2008 (alternating years with Best Article Award):

Chair, Michael Fultz, (2005-2008) University of Wisconsin-Madison

Chris Ogren, (2006-2009) University of Iowa

Adah Ward Randoph, (2006-2009) Ohio University

Christine Woyshner, (2006-2009) Temple University

Benita Blessing, (2007-2010) Ohio University

OUTSTANDING BOOK AWARD: The History of Education Society sponsors an Outstanding Book Award. This award of $\$ 1,000$ is made annually to the author of the best book published in the preceding year. 2007 Committee members: Karen Graves (Chair), Richard Angelo, Bethany Rogers

2007 Winner: Catherine Kerrison, Claiming the Pen: Women and Intellectual Life in the Early American Soutb (Cornell University Press, 2006).

2007 honorable mentions:

R. Scott Baker, Paradoxes of Desegregation: African American Struggles for Educational Equity in Charleston, South Carolina, 1926-1972 (University of South Carolina Press, 2006).

Mary S. Hoffschwelle, The Rasenwald Scbools of tbe American Soutb (University Press of Florida, 2006).

Outstanding Book Award Committee for 2008:

Chair, Richard Angelo, (2005-2008) University of Kentucky

Bethany Rogers, (2006-2009) College of Staten Island

Amy McCandless, (2007-2010) College of Charleston 
History of Education Quarterly

University of Illinois at Urbana-Champaign

360 Education Building, MC-708

1310 South Sixth Street, Champaign, IL 61820

Phone: 217 333-2446 (Office), Fax: 217 244-7064

http://www.ed.uiuc.edu/hes/INDEX.htm

Senior Editor

James D. Anderson, University of Illinois at Urbana-Champaign

$\begin{array}{cc}\text { Yoon K. Pak, } & \text { Co-Editors } \\ \text { University of Illinois at Urbana-Champaign } & \text { Christopher M. Span, }\end{array}$

Book Review Editor

Katrina M. Sanders-Cassell, University of lowa

David Adams, Cleveland State University

Associate Editors

$\begin{array}{ll}\text { Nancy Beadie, University of Washingtom, Seattle } & \text { Eileen Tamura, University of Hawaii } \\ \text { Timothy Cain, University of Illinois at Urbana-Champaign } & \text { Wayne Urban, University of Alabama }\end{array}$

Sharon S. Lee

\section{Editorial Assistants}

Evelyn A. Perez

Mario R. Perez

Editorial Board

\section{TERM EXPIRES IN 2010}

Carlos Blanton, Texas A\&M University

Benita Blessing, Obio University

James W. Fraser, New York University

Marybeth Gasman, University of Pennsylvania

Karen Graves, Denison University

K. Tsianina Lomawaima, University of Arizona

Jeffrey Mirel, University of Michigan

Kathleen Weiler, Tufts University

Joy Ann Williamson, University of Washington, Seattle

Robert S. Wolff, Central Connecticut State University

Roberta Wollons, University of Massachusetts, Boston

\section{TERM EXPIRES IN 2008}

Ian Grosvenor, University of Birmingham Jon Reyhner, Nortbern Arizona University Kim Tolley, Notre Dame de Namur University Clive Whitehead, University of Western Australia William Wraga, University of Georgia

\section{TERM EXPIRES IN 2009}

Mona Gleason, University of British Columbia Joyce Goodman, University of Wincbester Philo Hutcheson, Georgia State University W. Bruce Leslie, State University of New York, Brockport Gary McCulloch, University of London Adah Ward Randolph, Obio University Alan Sadovnik, Rutgers Unversity Joseph Watras, University of Dayton

The History of Education Society is an international scholarly society. Its purposes are to encourage and facilitate research in the history of education; to promote and improve the teaching of history of education; to encourage cooperation among specialists in history of education; and to promote an appreciation of the value of historical perspective in the making of educational policy. The Society is affiliated with the International Standing Conference for the History of Education, and members of the Society are automatically members of the Standing Conference.

\author{
President \\ Harold Wechsler, New York \\ University (2008)
}

\author{
Vice-President \\ Eileen Tamura, University of \\ Hawaii (2008)
}

\author{
Secretary-Treasurer \\ Robert Hampel, University of \\ Delaware (2006)
}

Nancy Beadie, University of Washington (2007)

Callie Waite, Columbia University (2006-2008)

\section{Directors}

Andrea Walton, Indiana University (2007-2009)

Jack Dougherty, Trinity College (2006-2008)

INDIVIDUAL MEMBERSHIP: Membership is open to all persons interested in the study of the history of education. Membership provides for subscription to the History of Education Quarterly; subscription to The Network, a newsletter published jointly with Division F of the American Educational Research Association; and receipt of the program of the annual meeting of the Society. Members of the Society are automatically members of the International Standing Conference for the History of Education. Membership offers subscription to publications on a calendar-year basis only. Dues are $\$ 25$ for students, $\$ 50$ for others. NonU.S. members should add \$7 to cover additional postage for surface mail; $\$ 20$ for airmail. To become a member, send a check for the appropriate amount in U.S. dollars only to Journal Customer Services, Blackwell Publishing Inc., 350 Main Street, Malden, MA 02148, USA, or to pay by credit card visit www.blackwellpublishing.com/journals/hoeq/members.htm

Make checks payable to Blackwell Publishing. Indicate preferred mailing address and the calendar year in which your subscription should begin. 
Article Submissions: Manuscripts must be submitted electronically to the History of Education Quarterly manuscript submission site, http://ojs.ed.uiuc.edu/index.php/heq/index. Questions regarding submissions can be directed to the editorial staff at heg@ed.uiuc.edu. See last page of this issue or our website www.blackwellpublishing.com/HOEQ for guidelines on submission. The editor will only consider articles that have been submitted exclusively to the History of Education Quarterly.

Book Reviews: Assignments of reviews are made from a file of potential reviewers. To have your name added to that file, send curriculum vitae to the book review editor. Requests to review particular books cannot be honored.

HISTORY OF EDUCATION QUARTERLY, (Print ISSN: 0018-2680 Online ISSN: 1748-5959), is published quarterly on behalf of the History of Education Society in conjunction with the College of Education, the University of Illinois at Urbana-Champaign, 360 Education Building, MC-708, 1310 South Sixth St., Champaign, IL 61820 by Wiley Subscription Services, Inc., a Wiley Company, 111 River St., Hoboken, NJ 07030-5774.

Mailing: Periodical Postage Paid at Hoboken, NJ and additional offices.

Postmaster: Send all address changes to HISTORY OF EDUCATION QUARTERLY, Journal Customer Services, John Wiley \& Sons Inc., 350 Main St., Malden, MA 02148-5020.

Publisher

History of Education Quarterly is published by Wiley Periodicals, Inc., Commerce Place, 350 Main Street, Malden, MA 02148; Telephone: 781388 8200; Fax: 7813888210

Wiley Periodicals, Inc. is now part of John Wiley \& Sons.

Journal Customer Services: For ordering information, claims and any enquiry concerning your journal subscription please contact your nearest office:

UK: Email: customerservices@blackwellpublishing.com; Tel: +44 (0) 1865 778315; Fax: +44 (0) 1865471775

USA: Email: customerservices@blackwellpublishing.com; Tel: +17813888599 or 18008356770 (Toll free in the USA \& Canada); Fax: +17813888232 or Fax: $+44(0) 1865471775$

Asia: Email: customerservices@blackwellpublishing.com; Tel: +65 6511 8000; Fax: +44 (0) 1865471775

Production Editor: James Lui (email: HOEQ@bos.blackwellpublishing.com)

Information for Subscribers

History of Education Quarterly is published in 4 issues per year. Subscription prices for 2008 are:

Premium Institutional: US\$136 (The Americas) $£ 80$ (Rest of World). Prices are exclusive of tax. Australian GST, Canadian GST and European VAT will be applied at the appropriate rates. For more information on current tax rates, please go to www.wiley.com, click on Help and follow the link through to Journal subscriptions. The Premium institutional price includes online access to the current and all online back files to January 1st 1997, where available. For other pricing options, including access information and terms and conditions, please visit www.interscience.wiley. com/journals

\section{Delivery Terms and Legal Title}

Prices include delivery of print journals to the recipient's address. Delivery terms are Delivered Duty Unpaid (DDU); the recipient is responsible for paying any import duty or taxes. Legal title passes to the customer on despatch by our distributors.

Back Issues: Single issues from current and recent volumes are available at the current single issue price from customerservices@blackwellpublishing.com. Earlier issues may be obtained from the Periodicals Service Company, 11 Main Street, Germantown, NY 12526, USA. Tel: +1 518537 4700, Fax: +1 518537 5899, Email: psc@periodicals.com

\section{Copyright and Photocopying}

C 2008 History of Education Society. All rights reserved. No part of this publication may be reproduced, stored or transmitted in any form or by any means without the prior permission in writing from the copyright holder. Authorization to photocopy items for internal and personal use is granted by the copyright holder for libraries and other users registered with their local Reproduction Rights Organisation (RRO), e.g. Copyright Clearance Center (CCC), 222 Rosewood Drive, Danvers, MA 01923, USA (www.copyright.com), provided the appropriate fee is paid directly to the RRO. This consent does not extend to other kinds of copying such as copying for general distribution, for advertising or promotional purposes, for creating new collective works or for resale. Special requests should be addressed to: jrights@wiley.com

Advertising: journalsusa@bos.blackwellpublishing.com

\section{Disclaimer}

The Publisher, History of Education Society, and Editors cannot be held responsible for errors or any consequences arising from the use of information contained in this journal; the views and opinions expressed do not necessarily reflect those of the Publisher, History of Education Society, and Editors, neither does the publication of advertisements constitute any endórsement by the Publisher, History of Education Society, and Editors of the products advertised.

This journal is available online at Blackwell Synergy. Visit www.blackwell-synergy.com to search the articles and register for table of contents e-mail alerts.

For submission instructions, subscription and all other information visit: www.blackwellpublishing.com/HOEQ

ISSN 0018-2680 (Print)

ISSN 1748-5959 (Online)

Printed in USA by The Sheridan Press 


\section{History \\ of Education \\ Quarterly}

Volume 48 • Number $3 \bullet$ August 2008

\section{Contents}

Articles

Making Broad Shoulders: Body-Building and Physical Culture in Chicago 1890-1920

David S. Churchill

A Silent Witness for Peace: The Case of Schoolteacher Mary Stone McDowell and America at War

Patricia Howlett and Charles F. Howlett

Beyond Civics and the 3 R's: Teaching Economics in the Schools

Andrew L. Yarrow

432

Defending the Faith through Education: The Catholic Case for Parental and Civil Rights in Victorian Britain Eric G. Tenbus

\section{Book Reviews}

Callaghan, Conservative Party Education Policies, 1976-1997: The Influence of Politics and Personality By Catberine A. Lugg

Comacchio, The Dominion of Youtb: Adolescence and the Making of Modern Canada, 1920-1950

By Don Romesburg Engagement with Dewey's Democracy and Education By Feanne Connell 
Herbst, School Choice and School Governance: A Historical Study' of the United States and Germany

By Gregory R. Zieren

470

Levin, Defining Memory: Local Museums and the Construction of History in America's Changing Communities

By Brenda Trofanenko

474

Marshall, The Social Origins of the Welfare State: Quebec

Families, Compulsory Education, and Family Allowances, 19401955. Translated from the French by Nicola Doone Danby By Kendall Taylor

477

Morrow, Sesame Street and the Reform of Children's Television By Daniel A. Clark

480

Murdoch, Imagined Orphans: Poor Families, Child Welfare, and Contested Citizenship in London

By Janet Fink

PHOTO CREDIT: Male students exercising, some with equipment, Western High School, Washington, D.C., 1899. Library of Congress Prints and Photographs Division Washington, D.C. Reproduction Number: LC-USZ62-14685. 